\title{
Multiple technical interest rates: A contribution to strengthening the stability of pension systems
}

\author{
Múltiples tasas de interés técnico: una contribución \\ al fortalecimiento de la estabilidad del sistema de pensiones
}

\author{
Héctor Alonso Olivares Aguayo* ${ }^{* 1}$, Gabriel Alberto Agudelo Torres ${ }^{2}$, \\ Luis Ceferino Franco Arbeláez² , Julio Téllez Pérez ${ }^{3}$ \\ ${ }^{1}$ Universidad La Salle, México \\ ${ }^{2}$ Instituto Tecnológico Metropolitano, Colombia \\ ${ }^{3}$ Universidad Anáhuac, México
}

Received January 16, 2019; accepted July 10, 2019

Available online August 1, 2019

\begin{abstract}
In actuarial science relative to pensions and life annuities, it is a common assumption that the discount rate used to calculate the adequate reserve amount to cover future payments is equal to the expected long-term return rate of portfolios in which it is invested. This assumption is inadequate because it could lead fund managers to take excessive risks in order to obtain greater profitability and not be aware that each future cash flow should have a discount rate in accordance with its payment date. This article demonstrates the existence of a suitable technical interest rate to discount each future payment. However, these rates are not necessarily equal among themselves and the expected long-term return of the portfolio. In order to estimate these technical interest rates, it is proposed to apply a risk model to

\footnotetext{
*Corresponding author.

E-mail address: hectoralonso.olivares@lasalle.mx (H. A. Olivares Aguayo).

Peer Review under the responsibility of Universidad Nacional Autónoma de México.

http://dx.doi.org/10.22201/fca.24488410e.2020.2407

0186-1042/@2019 Universidad Nacional Autónoma de México, Facultad de Contaduría y Administración. This is an open access article under the CC BY-NC-SA (https://creativecommons.org/licenses/by-nc-sa/4.0/)
} 
each of the expected payments, which incorporates the fluctuations of the portfolio in which the actuarial reserves are invested. Calculating appropriate discount rates to determine actuarial reserves contributes to strengthening the stability of pension systems and the financial system in general.

JEL code: $\mathrm{G} 22, \mathrm{G} 23, \mathrm{G} 32$

Keywords: Life annuity; Credit risk; Pension fund; Technical interest rate

\section{Resumen}

En la ciencia actuarial de vida relativa a pensiones y rentas vitalicias es un supuesto usual que la tasa de descuento utilizada para calcular el monto de reserva adecuado para cubrir los pagos futuros es igual a la tasa esperada de retorno de largo plazo de los portafolios en los cuales está invertida. Ese supuesto es inconveniente ya que podría llevar a los administradores de los recursos a tomar un exceso de riesgo con el fin de tener mayor rentabilidad e ignora que cada flujo de efectivo futuro debe tener una tasa de descuento acorde con su fecha de pago. En este artículo se demuestra la existencia de una tasa de interés técnico adecuada para descontar cada pago futuro y que dichas tasas no son necesariamente iguales entre sí, ni iguales al retorno esperado de largo plazo del portafolio. Para estimarlas se propone la utilización de un modelo de riesgo de incumplimiento en los pagos previstos, que incorpora las fluctuaciones propias del portafolio en el cual están invertidas las reservas actuariales. Determinar las tasas de descuento adecuadas para calcular reservas actuariales contribuye a fortalecer la estabilidad de los sistemas pensionales y del sistema financiero en general.

Código JEL: G22, G23, G32

Palabras clave: Renta vitalicia; Riesgo de crédito; Fondos de la pensión; Tasa de interés técnico

\section{Introduction}

The calculation of the actuarial reserve necessary to cover all the payments of a life annuity is a fundamental issue for insurance companies, as well as governments and public or private entities paying their own pensions. In actuarial science, that reserve is calculated as the sum of the expected present values of the possible payments. This calculation involves factors such as life expectancy, inflation, ages, the amount of the payment, and the discount rate, called "the technical interest rate". The estimation of the amount of these reserves directly affects the stability and coverage of pension systems and thus the quality of life of millions of people. Battocchio and Menoncin (2002) review the existing literature on pension plans and conclude that there are two types. On the one hand, there are defined-benefit plans, where the sponsor 
previously determines the benefits and the contributions adjust in order to maintain the balance of the fund. The second type is defined-contribution plans, in which the contributions are fixed and the future benefits depend on the returns of the portfolio. In addition, the authors affirm that many of the pension plans offered are based on defined-contribution schemes, transferring risk to the employees.

Regarding the design of alternative pension models or structural changes, Arellano (2018) performs an exploratory analysis of the design of non-contributory or social pensions implemented by local governments in Colombia, Spain, and Mexico. Josa-Fombellida and Rincón-Zapatero (2019) study "the optimal management of an aggregated overfunded pension plan of defined-benefit type as a two-player noncooperative differential game" and D’Amato, Di Lorenzo, and Sibillo (2017) propose a new contract with profit participation, which consists of a deferred life annuity with variable benefits changing according to two dynamic financial elements: the periodic financial result of the invested fund year by year, and the first-order financial technical base.

On the other hand, Krebs (2019) studies excessive saving in pension systems and inefficient capital allocations, specifically in Germany. For his part, Szabó (2017) uses modelling and simulation to present a possible scenario of changes in pension benefits in Hungary.

As described by Bodie and Crane (1999), the popularity of defined-contribution plans has two main reasons: i) the employee knows at any time the value of his/her retirement account, and ii) this type of plan is much easier to manage by the sponsor than the defined-benefit one.

In actuarial science relating to life annuities, it is generally assumed that the technical interest rate at which reserves are calculated to cover payments is equal to the expected rate of return of the portfolios where the reserves are invested, as indicated by Holsboer (2000) and Arango et al. (2013). This assumption is transversal to defined-contribution and defined-benefit plans, which is why the problem of choosing the best investment strategy to manage pension funds becomes extremely important in the management of such portfolios (Charupat \& Milevsky, 2002).

The expected rate of return of the portfolio is often considered as a discount rate for the calculation of reserves. This is a normal practice but not necessarily correct. According to Merton (2012), this situation could lead portfolio managers to take greater risks in order to have greater profitability and at the same time decrease their pension liabilities.

Multiple investigations have addressed the study of financial phenomena considering their stochastic dynamics. Some seminal works with this type of approach are Black and Scholes (1973), Merton (1973), Vasicek (1977), and Cox Ingersoll and Ross (1985a) and 
(1985b). Other works that generalize the Itô processes are Grinols and Turnovsky (1993) and Schmedders (1998).

Battocchio and Menoncin (2002) specify the behavior of the stochastic variables involved using the most common functional forms adopted in the literature.

This paper demonstrates that assuming the rate at which reserves are calculated to cover the payment of life annuities equals the expected rate of return of the portfolios in which they are invested is not appropriate, if the assumption of constant interest rates is abandoned and the stochastic nature of portfolio value is included within the analysis. In addition, a procedure is presented to find the technical interest rates that make the probability of default on each of the income payments equal to zero.

After this introduction, in section 2, the model is presented; in section 3, an application is shown, and section 4 presents some conclusions.

\section{Model}

Reserve needed for life annuity

Let $f(w)$ be a survival function that indicates the probability that the age of death () of a particular person is greater than a w age. Thus:

$$
f(w)=\mathbb{P}(W>w)
$$

${ }_{\tau} p_{w}$ is defined as the probability that a person of age $w$ does not die in the next $\tau$ years and ${ }_{\tau} q_{w}$ as the probability of dying in the same period. According to this definition, the following is obtained:

$$
\begin{array}{r}
{ }_{\tau} p_{w}=\mathbb{P}(W>w+\tau \mid W>w) \\
{ }_{\tau} p_{w}=\frac{\mathbb{P}(W>w \cap W>w+\tau)}{\mathbb{P}(W>w)} \\
{ }_{\tau} p_{w}=\frac{\mathbb{P}(W>w+\tau)}{\mathbb{P}(W>w)} \\
{ }_{\tau} p_{w}=\frac{f(w+\tau)}{f(w)}
\end{array}
$$


Therefore,

$$
{ }_{\tau} q_{w}=1-\frac{f(w+\tau)}{f(w)}=\frac{f(w)-f(w+\tau)}{f(w)}
$$

The reserve necessary for the payment of a life annuity shall be the sum of the expected present values of the possible payments:

$$
\begin{gathered}
R_{N}=E\left(\sum_{n=0}^{z \cdot w}\left(\text { Payment }_{n}\right)(1+i)^{-n}\right) \\
=E\left(\text { Payment }_{0}\right)(1+i)^{-0}+E\left(\text { Payment }_{1}\right)(1+i)^{-1} \\
+E\left(\text { Payment }_{2}\right)(1+i)^{-2}+\cdots+E\left(\text { Payment }_{z-w}\right)(1+i)^{-(z-w)} \\
R_{N}=\left(D_{00} p_{w}\right)(1+i)^{-0}+\left(D_{11} p_{w}\right)(1+i)^{-1}+\left(D_{22} p_{w}\right)(1+i)^{-2}+\cdots \\
+\left(D_{(z-w)(z-w)} p_{w}\right)(1+i)^{-(z-w)}
\end{gathered}
$$

where:

$D_{\tau}$ : Amount of the allowance at an instant

$i$ : Effective interest rate.

$w$ : Current age of the insured.

$z$-w: Maximum time that the insured can live.

$R_{N}$ : Reserve necessary for the payment of a life annuity.

For convenience, this article assumes a life annuity with an indemnity that increases by the same percentage as the general price level and that it initially corresponds to a value $D$ in the event of non-death and zero (0) in the event of death. Life annuities with the assumed characteristics are the most usual, as they allow the beneficiary to maintain purchasing power by transferring the market risk.

Assuming that $D_{\tau}$ corresponds to a present value $D$ updated with the percentage change in the general price level $(\rho)$, the necessary reserve is expressed as: 


$$
\begin{gathered}
R_{N}=\left(\sum_{n=0}^{\Omega-w}\left[D(1+\rho)^{n}{ }_{\mathrm{n}} p_{w}\right](1+i)^{-n}\right) \\
=\left[D(1+\rho)^{0}{ }_{0} p_{w}\right](1+i)^{-0}+\left[D(1+\rho)_{1}^{1} p_{w}\right](1+i)^{-1} \\
+\left[D(1+\rho)^{2}{ }_{2} p_{w}\right](1+i)^{-2}+\cdots+\left[D(1+\rho)_{(\Omega-w)}^{(\Omega-w)} p_{w}\right](1+i)^{-(\Omega-w)}
\end{gathered}
$$

Since the effective interest rate $(i)$ can be considered as the combination of the percentage change in the general price level $(\rho)$ and the real interest rate $(r)$, then:

$$
\begin{aligned}
& R_{N}=\left(\sum_{n=0}^{\Omega-w}\left[D(1+\rho)^{n}{ }_{\mathrm{n}} p_{w}(1+\rho)^{-n}(1+r)^{-n}\right]\right) \\
&= D(1+\rho)^{0}{ }_{0} p_{w}(1+\rho)^{-0}(1+r)^{-0}+D(1+\rho)^{1}{ }_{1} p_{w}(1+\rho)^{-1}(1+r)^{-1} \\
&+D(1+\rho)^{2}{ }_{2} p_{w}(1+\rho)^{-2}(1+r)^{-2}+\cdots \\
&+D(1+\rho)^{(\Omega-w)}{ }_{(\Omega-w)} p_{w}(1+\rho)^{-(\Omega-w)}(1+r)^{-(\Omega-w)} \\
& R_{N}=\left(D_{0} p_{w}\right)(1+r)^{-0}+D_{1} p_{w}(1+r)^{-1}+D_{2} p_{w}(1+r)^{-2}+\cdots+D_{(\Omega-w)} p_{w}(1+r)^{-(\Omega-w)}
\end{aligned}
$$

In continuous time,

$$
R_{N}=D \int_{0}^{\Omega-w}{ }_{\tau} p_{w} e^{-r * \tau} d \tau
$$

So that,

$$
\begin{gathered}
\lim _{k \rightarrow \infty}\left(1+\frac{1}{k}\right)^{k}=e \\
F V=P V \lim _{k \rightarrow \infty}\left(1+\frac{i^{(\mathrm{k})}}{k}\right)^{k \tau}=P V e^{i(\infty) \tau} \\
F V=P V e^{\delta \tau}
\end{gathered}
$$

where:

$k$ : Frecuency of capitalization of interest compost model with nominal interest rate. FV: Future Value.

$P V$ : Present Value. 


\section{Probability of default on payment}

Let $V_{t}$ be the value of the portfolio necessary to support the future payment $D_{T}$, with $0 \leq T \leq(\Omega-w)$, which will be realized as long as the person of age $w$ survives at least $T-t$ years more, therefore, the fund value corresponds to the actuarial present value:

$$
V_{t}=D_{(T-t)} p_{w} e^{-r *(T-t)}
$$

where $r$ is the real technical interest rate, ${ }_{(T-t)} p_{w}$ is the probability that a person of age $w$ survives at least $T-t$ years more and $D_{T}=D e^{\rho(r-t)}$, therefore $D=D_{T} e^{-\rho(T-t)}$.

Assume that the portfolio value $V_{t}$ is driven by the following Stochastic Differential Equation (SDE):

$$
d V_{t}=\mu_{v} V_{t} d t+\sigma_{v} V_{t} d W_{t}
$$

Note that at time T:

If $V_{T}<D_{T}$, there is failure to pay, at least partially, and there is no surplus $E_{T}$ in the portfolio that supports the life annuity, $E_{T}=0$.

If $V_{T} \geq D_{T}$, the obligation is fulfilled, thus $E_{T}>0$.

It is concluded that the surplus $E_{T}$ can be modeled as:

$$
E_{T}=\max \left(V_{T}-D_{T}, 0\right)
$$

It is known that a call option whose future payment is obtained from the following expression:

$$
C=\max \left(S_{T}-X, 0\right)
$$

where $S_{T}$ is the price of the asset at time $T$ and $X$ is the exercise price of the option. Using the equations of Black and Scholes (1973) and Merton (1973), the price at time $t$ of this option can be calculated with:

$$
c_{t}=S_{t} \mathrm{~N}\left(d_{1}\right)-X^{-\delta(T-t)} \mathrm{N}\left(d_{2}\right)
$$


where:

$$
\begin{gathered}
d_{1}=\frac{\operatorname{Ln}\left(\frac{S_{t}}{X}\right)+\left(\delta+\frac{1}{2} \sigma^{2}\right)(T-t)}{\sigma \sqrt{T-t}} \\
d_{2}=d_{1}-\sigma \sqrt{T-t}
\end{gathered}
$$

In accordance with the previous development, the present value of surplus $E_{t}$ is:

$$
E_{t}=V_{t} \mathrm{~N}\left(d_{1}\right)-D_{T} e^{-\mu_{v}^{(T-t)}} \mathrm{N}\left(d_{2}\right)
$$

where:

$$
d_{1}=\frac{\operatorname{Ln}\left(\frac{V_{t}}{D_{T}}\right)+\left(\mu_{v}+\frac{1}{2} \sigma_{v}^{2}\right)(T-t)}{\sigma_{v} \sqrt{T-t}}
$$

$\mathrm{N}(y)$ is the probability that a normally distributed variable with zero mean $(0)$ and standard deviation one (1) is less than $y$.

As $V_{t}=D_{T-t} p_{w} e^{-r(T-t)}$ and $D_{T}=D_{e^{\rho(T-t)}}$, therefore:

$$
d_{1}=\frac{\operatorname{Ln}\left({ }_{T-t} p_{w} e^{-(r+\rho)(T-t)}\right)+\left(\mu_{\left.v+\frac{1}{2} \sigma_{v}^{2}\right)(T-t)}\right.}{\sigma_{v} \sqrt{T-t}}
$$

Following Merton (1974), it is possible to calculate in the following way the probability of default, totally or partially, with the payment $D_{T}$ :

It is known that:

$$
\begin{gathered}
E_{t}=e^{-\mu_{v}(T-t)} \int_{-\infty}^{\infty} E_{T} f_{V_{T}} \mid V_{t}\left(V \mid V_{t}\right) d v \\
E_{t}=e^{-\mu_{v}(T-t)} \int_{-\infty}^{\infty} \max \left(v-D_{T}, 0\right) f_{V_{T} \mid V_{t}}\left(v \mid V_{t}\right) d v \\
E_{t}=e^{-\mu_{v^{(T-t)}}} \int_{D_{T}}^{\infty}\left(v-D_{T}\right) f_{V_{T} \mid V_{t}}\left(V \mid V_{t}\right) d v \\
E_{t}=e^{-\mu_{v}(T-t)} \int_{D_{T}}^{\infty} v f_{V_{T} \mid V_{t}}\left(v \mid V_{t}\right) d v-D_{T} e^{-\mu_{v}(T-t)} \int_{\left\{v>D_{T}\right\}}^{\infty} f_{V_{T} \mid V_{t}}\left(V \mid V_{t}\right) d v
\end{gathered}
$$




$$
E_{t}=e^{-\mu_{v^{(T-t)}}} E\left[V_{T\left\{v>D_{T}\right\}} \mid V_{t}\right]-D_{T} e^{-\mu_{v^{(T-t)}}} \mathbb{P}\left\{V_{T}>D_{T} \mid V_{t}\right\}
$$

where $f_{V_{T} \mid V_{t}}\left(V \mid V_{t}\right)$ is the probability density function of $V_{T}$, conditional on the initial value $V_{t}$.

As $E_{t}=V_{t} \mathrm{~N}\left(d_{1}\right)-D_{T} e^{-\mu_{v}(T-t)} \mathrm{N}\left(d_{2}\right)$, then:

$$
\mathbb{P}\left\{V_{T}>D_{T} \mid V_{t}\right\}=\mathrm{N}\left(d_{2}\right)
$$

Therefore, the probability of default will be:

$$
\mathbb{P}\left\{V_{T}<D_{T} \mid V_{t}\right\}=1-\mathrm{N}\left(d_{2}\right)
$$

And for the latter to be zero, it is necessary that $\mathrm{N}\left(d_{2}\right)=1$.

\section{Estimation of the technical interest rate}

Bearing in mind that $E_{t}=V_{t} \mathrm{~N}\left(d_{1}\right)-D_{T} e^{-\mu v^{*}(T-t)} \mathrm{N}\left(d_{2}\right)$, it can be deduced for the Itô lemma that:

$$
d E_{t}=\left(\frac{\partial E_{t}}{\partial t}+\mu_{v} V_{t} \frac{\partial E_{t}}{\partial V_{t}}+\frac{1}{2} \sigma_{v}^{2} V_{t}^{2} \frac{\partial^{2} E_{t}}{\partial V_{t}^{2}}\right) d_{t}+\sigma_{v} V_{t} \frac{\partial E_{t}}{\partial V_{t}} d W_{t}
$$

Assuming that the surplus $E_{t}$ is driven by the process $d E_{t}=\mu_{s} E_{t} d t+\sigma_{s} E_{t} d W_{t}$, then:

$$
\mu_{S} E_{t} d t+\sigma_{S} E_{t} d W_{t}=\left(\frac{\partial E_{t}}{\partial_{t}}+\mu_{v} V_{t} \frac{\partial E_{t}}{\partial V_{t}}+\frac{1}{2} \sigma_{v}^{2} V_{t}^{2} \frac{\partial^{2} E_{t}}{\partial V_{t}^{2}}\right) d_{t}+\sigma_{v} V_{t} \frac{\partial E_{t}}{\partial V_{t}} d W_{t}
$$

Since the stochastic components must be equal:

$$
\sigma_{S} E_{t}=\sigma_{v} V_{t} \frac{\partial E_{t}}{\partial V_{t}}
$$

As $E_{t}=V_{t} \mathrm{~N}\left(d_{1}\right)-D_{T} e^{-\mu_{v}(T-t)} \mathrm{N}\left(d_{2}\right)$, then $\frac{\partial E_{t}}{\partial V_{t}}=\mathrm{N}\left(d_{1}\right)$, therefore:

$$
\begin{aligned}
& \sigma_{S} E_{t}=\sigma_{v} V_{t} \mathrm{~N}\left(d_{1}\right) \\
& E_{t}=\frac{\sigma_{v}}{\sigma_{S}} V_{t} \mathrm{~N}\left(d_{1}\right)
\end{aligned}
$$

Replacing this last expression in $E_{t}=V_{t} \mathrm{~N}\left(d_{1}\right)-D_{T} e^{-\mu_{v^{(r-t)}}} \mathrm{N}\left(d_{2}\right)$, the following is obtained:

$$
\frac{\sigma_{v}}{\sigma_{S}} V_{t} \mathrm{~N}\left(d_{1}\right)=V_{t} \mathrm{~N}\left(d_{1}\right)-D_{T} e^{-\mu_{v^{(T-t)}}} \mathrm{N}\left(d_{2}\right)
$$


$\hat{\sigma}_{s}$ is observable, as are $\hat{\mu}_{v}$ and $\hat{\sigma}_{v}$, if a portfolio has already been constituted to guarantee the life annuity. Consequently it is possible to solve the following equation for the real technical interest rate r; subject to the constraint that the probability of default is zero, $\mathbb{P}\left\{V_{T}<D_{T} \mid V_{t}\right\}=1-\mathrm{N}\left(d_{2}\right)=0$, therefore:

$$
0=V_{t} \mathrm{~N}\left(d_{1}\right)\left(1-\frac{\hat{\sigma}_{v}}{\hat{\sigma}_{s}}\right)-D_{T} e^{-\hat{\mu}_{v}(T-t)}
$$

which is the same as:

$$
0=D_{(T-t)} p_{W} e^{-r(T-t)} \mathrm{N}\left(d_{1}\right)\left(1-\frac{\hat{\sigma}_{v}}{\hat{\sigma}_{S}}\right)-D_{T} e^{-\hat{\mu}_{v}(T-t)}
$$

where (equation 32):

$$
\begin{gathered}
d_{1}=\frac{\operatorname{Ln}\left((T-t) p_{W} e^{-(r+\rho)(T-t)}\right)+\left(\hat{\mu}_{v}+\frac{1}{2} \hat{\sigma}_{v}^{2}\right)(T-t)}{\hat{\sigma}_{v} \sqrt{T-t}} \\
d_{2}=d_{1}-\hat{\sigma}_{v} \sqrt{T-t}
\end{gathered}
$$

Assuming that $V_{t}=D_{(T-t)} p_{w} e^{-r(T-t)}$.

As $D_{T}=D_{e} \rho(T-t)$, then

$$
\begin{gathered}
0=D_{(T-t)} p_{w} e^{-r(T-t)} \mathrm{N}\left(d_{1}\right)\left(1-\frac{\hat{\sigma}_{v}}{\hat{\sigma}_{s}}\right)-D e^{\rho(T-t)} e^{\hat{\mu}_{v}(T-t)} \\
0=D_{(T-t)} p_{w} e^{-r(T-t)} \mathrm{N}\left(d_{1}\right)\left(1-\frac{\hat{\sigma}_{v}}{\hat{\sigma}_{s}}\right)-D e^{-\left(\hat{\mu}_{v}-\rho\right)(T-t)} \\
0={ }_{(T-t)} p_{w} e^{-r(T-t)} \mathrm{N}\left(d_{1}\right)\left(1-\frac{\hat{\sigma}_{v}}{\hat{\sigma}_{s}}\right)-e^{-\left(\hat{\mu}_{v}-\rho\right)(T-t)}
\end{gathered}
$$

Finally, removing the constraint $\mathbb{P}\left\{V_{T}<D_{T} \mid V_{t}\right\}=0$, (equation 37) is obtained:

$$
0={ }_{(r-t)} p_{w} e^{-r(r-t)} \mathrm{N}\left(d_{1}\right)\left(1-\frac{\sigma_{v}}{\hat{\sigma}_{s}}\right)-e^{-\left(\hat{\mu}_{v}-\rho\right)(r-t)} \mathrm{N}\left(d_{2}\right)
$$

The above procedure makes it possible to find a different real technical interest rate for each payment to be made. The full actuarial calculation, as an approximation, would then be:

$$
V_{t}=D_{0} p_{w} e^{-\hat{r}_{0}^{* 0}}+D{ }_{1} p_{w} e^{-\hat{r}_{1}^{*} 1}+D_{2} p_{w} e^{-\hat{r}_{2}^{* 2}}+\cdots+D_{\Omega-w} p_{w} e^{-\hat{r}(\Omega-w)^{*(\Omega-w)}}
$$




\section{Application}

In Colombia, the Fondo de Pensiones de las Entidades Territoriales (FONPET) is a fund set up by the Ministry of Finance and Public Credit to support the payment of the pensions of former employees throughout the Colombian territory. FONPET is defined as " a fund without legal status administered by the Ministry of Finance and Public Credit, which aims to collect and allocate resources to the accounts of the territorial entities and administer the resources through the autonomous assets" (Dirección de Inversiones y Finanzas Públicas, 2017).

Today, FONPET manages approximately $\$ 16$ billion USD, and is the largest and most important fund in the country. The financial stability of departments, municipalities, and other governmental entities depends on the proper administration of this fund.

Figure 1 shows the evolution of the per unit return of FONPET from January 1, 2013 to November 21,2018 . In this period, its annual profitability was $\hat{\mu}_{v}$ and its annual volatility $\hat{\sigma}_{v}=1.77 \%$.

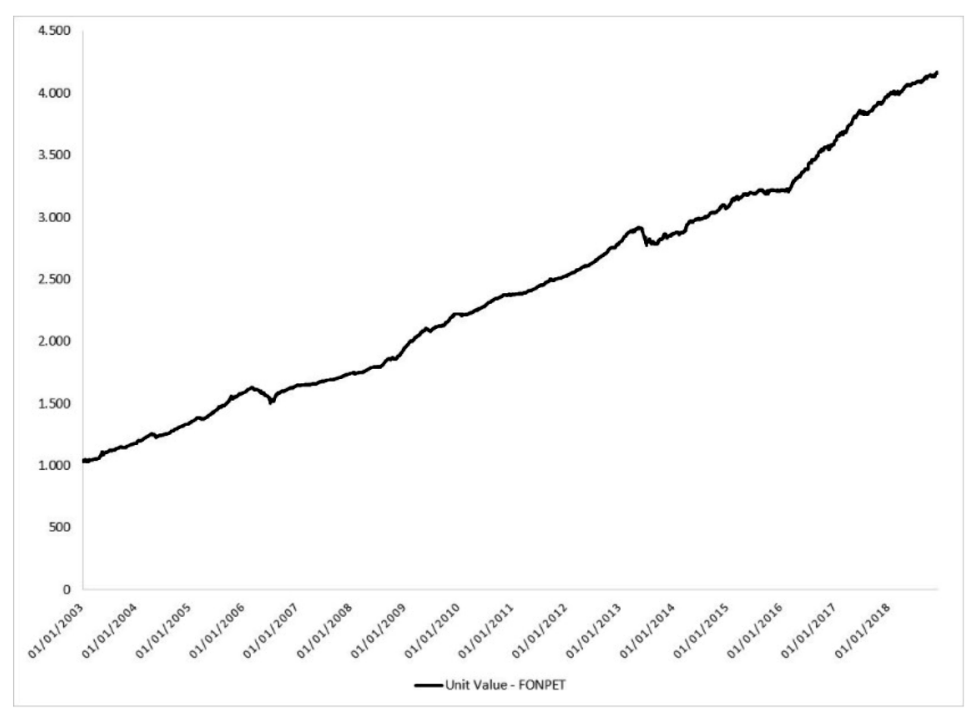

Figure 1. Return of FONPET (2013-2018).

Source: Prepared by author with Excel 2016.

Regarding the volatility of the surplus $\left(\sigma_{s}\right)$, its annual estimate is $\hat{\sigma}_{s}=166.34 \%$ and is calculated thus: 


$$
\hat{\sigma}_{s}=\left[\sqrt{\frac{\sum\left(L_{t}-\bar{L}_{t}\right)^{2}}{n-1}}\right] \sqrt{252}
$$

Where,

$$
L_{t}=\ln \left(\frac{E_{t}}{E_{t-1}}\right)
$$

And the surplus is,

$$
E_{t}=\max \left(V_{t}-V_{T} e^{-\frac{\mu_{s}}{252}(T-t)}, 0\right)
$$

If an inflation rate of $3 \%$ is assumed, the technical interest rate can be found by applying equations 36 and 32 as follows:

$$
\begin{gathered}
0={ }_{(T-t)} P_{w} e^{-r(T-t) \mathrm{N}\left(d_{1}\right)\left(1-\frac{1.77 \%}{166.34 \%}\right)-e^{-(6.01 \%-3 \%)(T-t)}} \\
d_{1}=\frac{\operatorname{Ln}\left({ }_{(T-t)} p_{W} e^{-(r+3 \%)(T-t))+\left(6.01 \%+\frac{1}{2}(1.77 \%)^{2}\right)(T-t)}\right.}{1.77 \% \sqrt{T-t}}
\end{gathered}
$$

In Colombia, the retirement age in the public pension system is 62 for men and 57 for women. For the case of a 62-year-old man, the actuarial calculation should consider the technical interest rates shown in Figure 2. Under the traditional methodology, considering a portfolio's profitability of $6.01 \%$ and inflation rate of $3.0 \%$ per year, the technical annual interest rate used will be $3.01 \%$. In the perspective of multiple technical interest rates, only the flow of year 17 must be discounted at that interest rate.

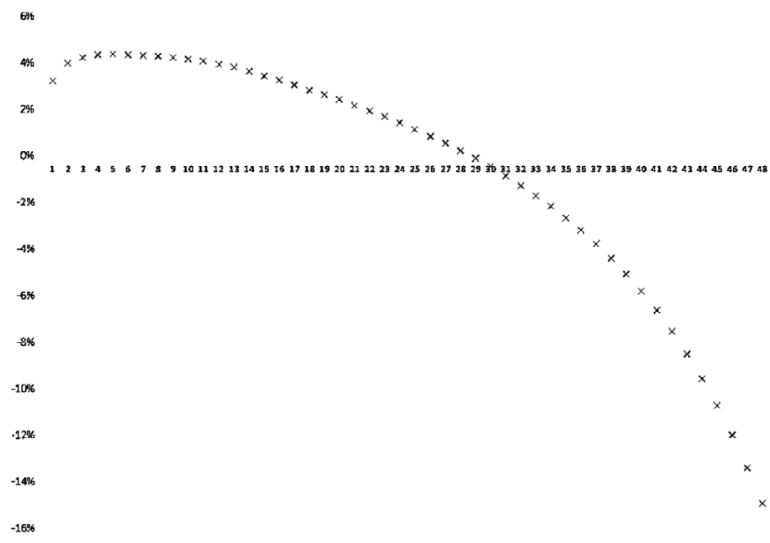

Figure 2. Technical interest rates of a 62-year-old man. Source: Prepared by author with Excel 2016. 
Through the traditional methodology, the same technical interest rate is applied in each of the possible cash flows as it is in the case of Colombia. Now, considering annual payments of \$12 000 USD through time, the value of the reserve will be \$168 247 USD under the traditional methodology, with a technical interest rate of $4 \%$ per year. Through the proposed methodology, the value of the reserve will be \$222 408 USD. It is clearly observed that the inherent risk of this life annuity is underestimated by the current system.

To analyze scenarios in which the profitability of the reserve changes, a structure of coefficients of constant variation was assumed.

$$
\begin{aligned}
& \frac{\hat{\sigma}_{v}}{\hat{\mu}_{v}}=0.293458 \\
& \frac{\hat{\sigma}_{S}}{\hat{\mu}_{v}}=27.654655
\end{aligned}
$$

Based on this structure, scenarios of true profitability minus $3 \%, 2 \%$, and $1 \%$, and true profitability plus $1 \%, 2 \%$, and $3 \%$ were simulated. The results are shown in Figure 3.

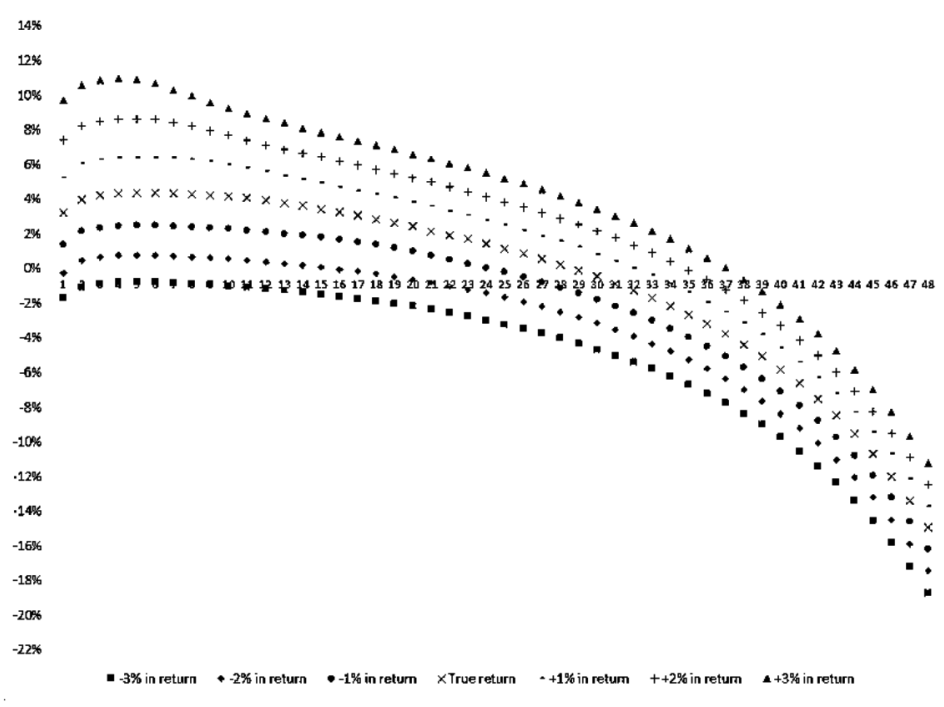

Figure 3. Scenarios of profitability simulation. Source: Prepared by author with Excel 2016.

As shown in Table 1, adding an additional $2 \%$ to the profitability of the fund would result in a decrease in the actuarial reserve required. On the other hand, it can be seen that the risk 
is being underestimated since the client is being required to pay \$168 247 USD, while the calculations estimate this reserve at \$222 408 USD.

Table 1

Profitability vs Actuarial Reserve for a 62-year-old man

\begin{tabular}{llll}
\hline Return & Actuarial Reserve & $\begin{array}{l}\text { Change }(\%) \\
\text { Today vs. Scenarios }\end{array}$ & $\begin{array}{l}\text { Change (\%) } \\
\text { (add 1\% in return) }\end{array}$ \\
\hline Today (rtech=4\%) & 168247 & & \\
$-3 \%$ in return & 503858 & $199.48 \%$ & \\
$-2 \%$ in return & 369916 & $119.87 \%$ & $-26.6 \%$ \\
$-1 \%$ in return & 282162 & $67.71 \%$ & $-23.7 \%$ \\
True return & 222408 & $32.19 \%$ & $-21.2 \%$ \\
$+1 \%$ in return & 180238 & $7.13 \%$ & $-19.0 \%$ \\
$+2 \%$ in return & 149381 & $-11.21 \%$ & $-17.1 \%$ \\
$+3 \%$ in return & 126522 & $-24.80 \%$ & $-15.3 \%$ \\
\hline
\end{tabular}

Source: Prepared by author with Excel 2016.

Another effect that is observed in Table 1 is that an increase in profitability produces a decrease in the actuarial reserve required.

For the case of a 57-year-old woman, the results are presented in Figure 4 and Table 2.

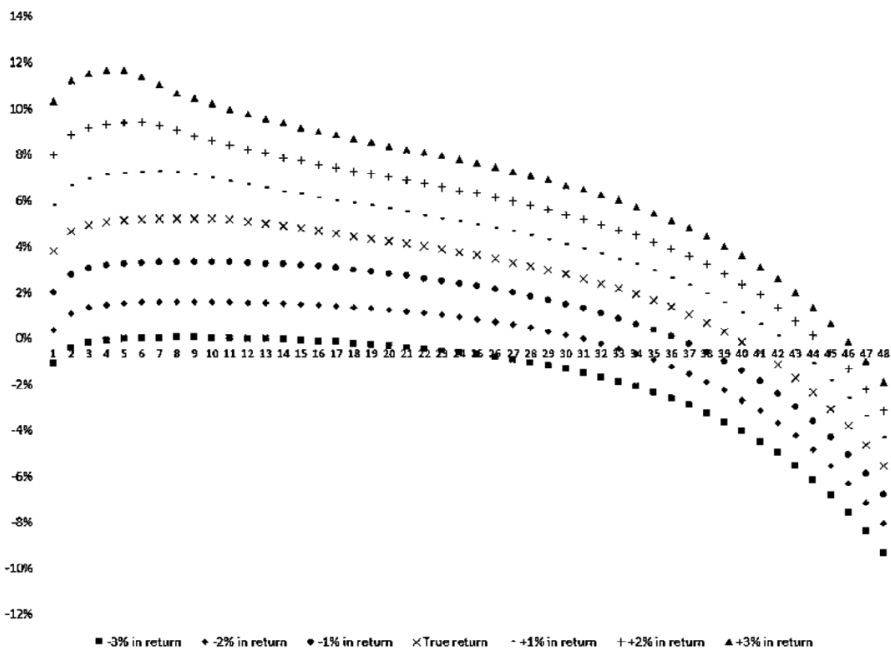

Figure 4. Technical interest rates of a 57-year-old woman. Source: Prepared by author with Excel 2016. 
Table 2

Profitability vs Actuarial Reserve for a 57-year-old woman

\begin{tabular}{llll}
\hline Return & Actuarial Reserve & $\begin{array}{l}\text { Change (\%) Today vs. } \\
\text { Scenarios }\end{array}$ & $\begin{array}{l}\text { Change (\%) } \\
\text { (add 1\% in return) }\end{array}$ \\
\hline Today (rtech=4\%) & 246555 & & \\
$-3 \%$ in return & 510368 & $107.00 \%$ & $-26.6 \%$ \\
$-2 \%$ in return & 374765 & $52.00 \%$ & $-23.3 \%$ \\
$-1 \%$ in return & 287572 & $16.64 \%$ & $-21.7 \%$ \\
True return & 225309 & $-8.62 \%$ & $-18.8 \%$ \\
$+1 \%$ in return & 182947 & $-25.80 \%$ & $-16.9 \%$ \\
$+2 \%$ in return & 152029 & $-38.34 \%$ & $-15.5 \%$ \\
$+3 \%$ in return & 128521 & $-47.87 \%$ & \\
\hline
\end{tabular}

Source: Prepared by author with Excel 2016Excel 2016.

In this case, Table 2 shows that the current real yield produces a reduction of $8.62 \%$ in the actuarial reserve required compared to what is required. In this case, the risk is being overestimated.

It is also observed that an additional real profitability of $1 \%$ would produce a $25.8 \%$ decrease in the actuarial reserve required.

If it is a group life annuity, in which if the owner dies another person will inherit the payments, the equations for this system are:

$$
\begin{aligned}
& 0=\left[{ }_{(T-t)} p \frac{1}{x_{1}, x_{2}}\right] e^{-r(T-t)} \mathrm{N}\left(d_{1}\right)\left(1-\frac{\hat{\sigma}_{v}}{\hat{\sigma}_{s}}\right)-e^{-\left(\hat{\mu}_{v}-\rho\right)(T-t)} \mathrm{N}\left(d_{2}\right) \\
& d_{1}=\frac{\operatorname{Ln}\left(\left[{ }_{(T-t)} p \frac{1}{x_{1}, x_{2}}\right] e^{-(r+\rho)(T-t)}\right)+\left(\hat{\mu}_{v}+\frac{1}{2} \hat{\sigma}_{v}^{2}\right)(T-t)}{\hat{\sigma}_{v} \sqrt{(T-t)}}
\end{aligned}
$$

Where, (T-t) $p \frac{1}{x_{1}, x_{2}}$ is the probability that, of a group consisting of two people with information $x_{1}$ and $x_{2}$ respectively, at least one (1) of them will survive, at least $T-t$ years more.

Supposing a couple is composed of a 57-year-old woman and a 62-year-old man, the results shown in Figure 5 and Table 3 are obtained. 


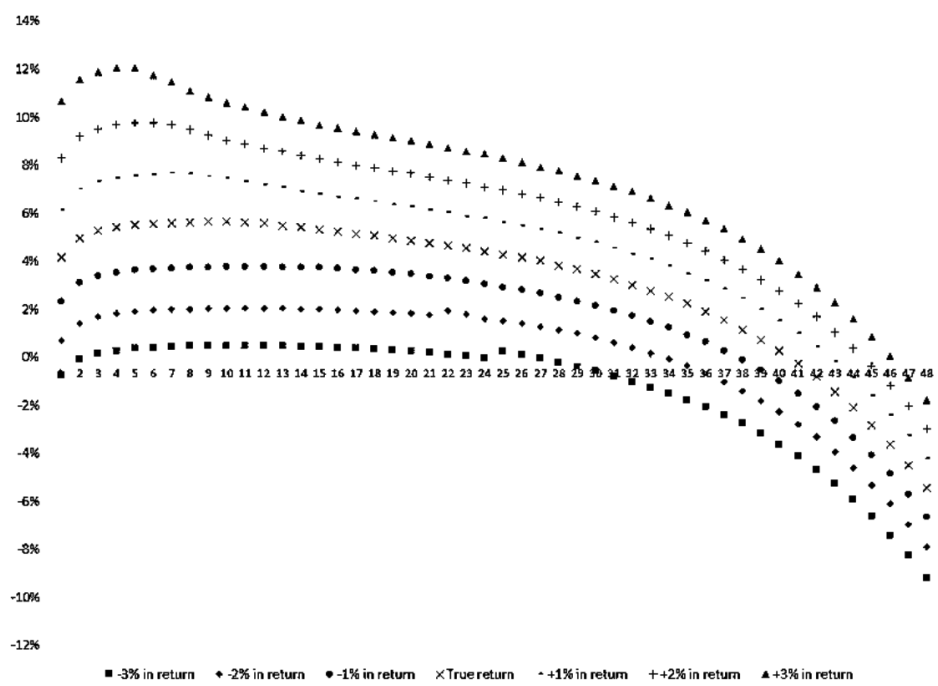

Figure 5.Multiple technical interest rates for a couple consisting of a 57-year-old woman and a 62-year-old man. Source: Excel 2016.

Table 3

Profitability vs Actuarial Reserve for a couple consisting of a 57-year-old woman and a 62-year-old man

\begin{tabular}{llll}
\hline Return & Actuarial Reserve & $\begin{array}{l}\text { Change }(\%) \\
\text { Today vs. Scenarios }\end{array}$ & $\begin{array}{l}\text { Change (\%) } \\
\text { (add 1\% in return) }\end{array}$ \\
\hline Today (rtech=4\%) & 262095 & & \\
$-3 \%$ in return & 494676 & $88.74 \%$ & $-25.9 \%$ \\
$-2 \%$ in return & 366366 & $39.78 \%$ & $-23.0 \%$ \\
$-1 \%$ in return & 282177 & $7.66 \%$ & $-21.3 \%$ \\
True return & 221951 & $-15.32 \%$ & $-18.6 \%$ \\
$+1 \%$ in return & 180714 & $-31.05 \%$ & $-16.7 \%$ \\
$+2 \%$ in return & 150522 & $-42.57 \%$ & $-15.2 \%$ \\
$+3 \%$ in return & 127645 & $-51.30 \%$ & \\
\hline
\end{tabular}

Source: Prepared by author with Excel 2016. 
In this case, using multiple technical interest rates makes it possible to reduce the cost of a life annuity granted by the national, departmental, or municipal governments by more than $15 \%$. This is done while maintaining the same profitability and volatility of the FONPET portfolio.

Increasing the portfolio's $1 \%$ return would allow a $31 \%$ decrease in the cost of that particular annuity.

\section{Conclusions}

This document shows a procedure to calculate the technical interest rates that should be used to discount each possible payment in the actuarial reserve necessary for a life annuity.

This method is constructed from the model of Merton (1974) to estimate the probabilities of default in corporate bonds. It is an alternative to the traditional option of assuming a constant and equal discount rate for all cash flows, which is usually the expected long-term yield of the portfolio, as is shown in Bowers, Gerber, Hickman, Jones, and Nesbitt (1997), Arango (2013), D’Amato, V., Di Lorenzo, E., and Sibillo, M. (2017), and Szabó (2017).

In addition, the effects of its application to the Pension Fund of Territorial Entities (FONPET) in Colombia were analyzed. The effect of using multiple technical interest rates on actuarial reserves calculated for a 62-year-old man, a 57-year-old woman, and a couple with the same sexes and ages previously described, was estimated.

In the case of the 62-year-old man, using this method with the rates of profitability and historical volatility of the FONPET will imply an increase of $32.19 \%$ in the actuarial reserve required. Applying it to the 57-year-old woman will imply a decrease of $8.62 \%$ and applying it to an annuity of two lives (62-year-old man and 57-year-old woman) will have an effect of $-15.32 \%$.

Future research can deal with the effects that this method would have on the reduction of Colombia's fiscal deficit as a particular case.

\section{References}

Arango, L.E. Cabrera, \& W. Gómez, E. (2013). Tasa de interés de largo plazo, interés técnico y pasivo pensional. Borradores de Economía. Banco de la Republica de Colombia. No 796.

Arellano, J. (2018). The Design of Social Pensions in Local Governments of Ibero-America. Revista del CLAD Reforma y Democracia, (71), 189-218.

Battocchio, P., \& Menoncin, F. (2002). Optimal Pension Management under Stochastic. In Interest Rates, Wages, and Inflation," Discussion Papers 2002021, Université Catholique de Louvain.

Black, F. \& M. Scholes (1973). The Pricing of Option and Corporative Liabilities. Journal of Political Economy, Vol. 81, No 3, pp. 637-654. 
Bodie, Z., \& Crane, D.B. (1999). The design and production of new retirement savings products. The Journal of Portfolio Management 25, 77-82.

Bowers, N. L., Gerber, H. U., Hickman, J. C., Jones, D.A. and Nesbitt, C. J. (1997). Actuarial Mathematics, 2nd edition. Itasca: Society of Actuaries.

Charupat, N., \& Milevsky, M. (2002). Optimal asset allocation in life annuities. Insurance: Mathematics and Economics 30, 199-209.

Cox, J., J. Ingersoll \& S. Ross (1985a). An Intertemporal General Equilibrium Model of Asset Prices, Econometrica, Vol. 53, No. 2, pp. 385-467.

Cox, J., J. Ingersoll \& S. Ross (1985b). A theory of the term structure of interest rates, Econometrica, Vol. 53, No. 2, pp. 385-467.

D’Amato, V., Di Lorenzo, E., \& Sibillo, M. (2017). New Challenges in Pension Industry: Proposals of Personal Pension Products. In Italian Workshop on Neural Nets (pp. 253-263). Springer, Cham.

Dirección de Inversiones y Finanzas Públicas (2017). Panorama actual de los recursos del Fondo Nacional de Pensiones de las Entidades Territoriales (FONPET). Dirección Nacional de Planeación. pp 31.

Grinols, E. L. \& S. J. Turnovsky (1993). Risk, the Financial Market, and Macroeconomic Equilibrium, Journal of Economic Dynamics and Control, Vol. 17, No. 1-2, pp. 1-36.

Holsboer, J. H. (2000). The Impact of Low Interest Rates on Insurers. The Geneva Papers on Risk and Insurance, 25 (1), 38-58, 2000.

Josa-Fombellida, R., \& Rincón-Zapatero, J. P. (2019). Equilibrium strategies in a defined benefit pension plan game. European Journal of Operational Research, 275(1), 374-386.

Krebs, T. (2019). Grundzüge einer effizienten Altersvorsorge. Wirtschaftsdienst, 99(1), 32-35.

Merton, R. (1973). Theory of Rational Option Pricing. Bell Journal of Economics, Vol. 4, No. 1, pp. 141-183.

Merton, R. (1974). On the Pricing of Corporate Debt: The Risk Structure of Interest Rates. The Journal of Finance, Vol. 29, No. 2, pp. 449-470.

Merton, R. (2012). Introduction to Pension Finance. M. Barton Waring, Wiley Finance.

Schmedders, K. (1998). Computing Equilibria in the General Equilibrium Model with Incomplete Asset Markets. Journal of Economic Dynamics and Control, Vol. 22, No. 8-9, pp. 1375-1401.

Szabó, Z. (2017, November). The modelling and simulation of the pension system. In 2017 IEEE 30th Neumann Colloquium (NC) (pp. 000025-000028). IEEE.

Vasicek O. (1977). An equilibrium characterization of the term structure. Journal of Financial Economics 5: 177188. 